\title{
Plant spacing effects on seed yield and quality of carrot cultivar T-29
}

\author{
Anam Noor ${ }^{1}$, Khurram Ziaf ${ }^{*}$, Muhammad Awais Ghani ${ }^{1}$, Chaudhary \\ Muhammad Ayub ${ }^{1}$, Iftikhar Ahmad ${ }^{1}$ and Muhammad Amjad ${ }^{1}$ \\ Institute of Horticultural Sciences, University of Agriculture, Faisalabad-38040-Pakistan \\ *Corresponding author's email: khurramziaf@uaf.edu.pk ; kziaf78@yahoo.com \\ Citation \\ Anam Noor, Khurram Ziaf, Muhammad Awais Ghani, Chaudhary Muhammad Ayub, Iftikhar Ahmad and \\ Muhammad Amjad. Plant spacing effects on seed yield and quality of carrot cultivar T-29. Pure and Applied \\ Biology. Vol. 9, Issue 4, pp2563-2570. http://dx.doi.org/10.19045/bspab.2020.90272
}

\begin{tabular}{llll}
\hline \hline Received: 23/04/2020 & Revised: 01/07/2020 & Accepted: 08/07/2020 & Online First: 06/08/2020 \\
\hline \hline
\end{tabular}

\section{Abstract}

Carrot is a direct seeded vegetable crop and plant population is primarily dependent on seed quality, besides several other factors. But, unfortunately vegetable seed production in Pakistan remained neglected and regarding standardization of numerous features for production of carrot seed crop, limited work has been done. This experiment was conducted to optimize the plant spacing for carrot seed crop. Stecklings of carrot cultivar (cv.) T-29 were planted at 15, 22.5, or $30 \mathrm{~cm}$ plant-to-plant spacing keeping row spacing of $75 \mathrm{~cm}$. Results revealed that number of secondary and tertiary umbels per plant, yield of seed per umbel and per plant, 1000-seed weight per umbel, vigour index, germination index and seedling length of all umbel order seeds were higher for the plant spacing at $30 \mathrm{~cm}$, while time taken to $50 \%$ germination $\left(\mathrm{T}_{50}\right)$ was significantly reduced compared to other treatments. However, appreciable (28.3\% and $16.55 \%)$ increase in seed yield per plot was noted for narrow intra-row spacing $(15 \mathrm{~cm})$ compared to 30 and $22.5 \mathrm{~cm}$ spacing, respectively. Moreover, $15 \mathrm{~cm}$ intra-row spacing resulted in comparable seed germination $(77.53 \%)$ compared with $22.5 \mathrm{~cm}(80 \%)$ and $30 \mathrm{~cm}(82 \%)$ spacing. But, seeds from closest spacing cannot be stored for long duration because of relatively low vigour (568.13) compared to $22.5 \mathrm{~cm}$ (630.33) and $30 \mathrm{~cm}$ (684.1) spacing. Therefore, for acquiring high return of good quality seed and long storage, growers can grow carrot seed crop at 22 or $30 \mathrm{~cm}$ spacing.

Keywords: Daucus carota; Planting geometry; Stecklings; Seed vigour; Umbel order

\section{Introduction}

Carrot (Daucus carota L.) from family Apiaceae is a biennial vegetable crop, cultivated worldwide for its roots [1]. Carrots of many colors provide important nutrient and bioavailable phytochemicals that act as a functional food. The storage root due to its richness in carotenoids, anthocyanins, dietary fiber, minerals and antioxidants are becoming more popular and valuable [2]. Carrot produces edible root for fresh consumption in one (winter) growing season and seeds in next (spring-early summer) season [3].

World production of carrot is estimated to be about 27.39 million tonnes per year, on area of 9, 90 thousand hectares [4]. Carrot in Pakistan was grown on an area of 13.95 thousand ha during the year 2017-18 and its production was 241.91 thousand tonnes [5]. It occupies $3^{\text {rd }}$ position among winter vegetables grown in Pakistan. Major carrot 
growing district in Punjab, the major carrot producing province, are Sheihupura and Qasur and contributing about 39\% of the total production in Punjab [6]. Carrot varieties grown in Punjab are numerous but promising are Praline, Durga, Maha Rani, Red Core and Red Lady.

Unavailability of required quantity of good quality seed is one of the main problem faced by growers. Thus, to improve the carrot productivity locally, accessibility of quality seed is crucial [7]. Due to small scale production and low quality of local carrot seed produced in Pakistan, a large quantity of the seed accessible in the market is imported from other countries. Both, less production and poor quality can be attributed to lack of optimized seed production technology of vegetable crops, starting from seed planting to harvesting and postharvest treatment of seed [8].

Besides various factors, production of good quality seed is also affected by umbel position (primary, secondary or tertiary) and planting density. Seeds from primary and secondary umbel orders are generally of superior quality compared to tertiary umbels [9]. Therefore, optimum spacing between plants play crucial role in the yield and seed quality of carrot [10]. Planting pattern significantly influences the encompassing condition of the seed crop field, which alters the harvest phenology [11], eventually influencing the yield [12] and seed quality [13].

Optimized plant spacing is of prime importance to proliferate the biomass production and nutritional availability to plants and ultimately affect the seed quality $[14,15]$. Optimal row spacing among the crop plants helps to avoid shading effect on plants as well as competition for soil moisture and nutrient elements among the plants. Appropriate plant spacing is essential for maximum seed yield of carrot because it minimizes competition for nutrition, light and water [16]. Optimal row spacing in forage turnip significantly influenced seed yield and yield components [17]. Likewise, attack of diseases (Alternaria sp.) in radish [18] and the crop lodging was observed in narrow spaced seed crops $[17,18]$.

Previous study indicated that narrow plant spacing $(15 \mathrm{~cm})$, keeping $60 \mathrm{~cm}$ inter-row spacing, resulted in highest seed yield of carrot cv. T-29 compared to 22.5 or $30 \mathrm{~cm}$ spacing [19], but impact of various spacings on seed quality was not assessed in that study. Hence, this study was conducted to find out the most suitable intra-row spacing for producing higher yield of good quality seed of carrot cv. T-29.

\section{Materials and methods Experimental site}

Experiment was conducted at Vegetable Experimental Area (Latitude $31^{\circ} 31 \mathrm{~N}$, Longitude $73^{\circ} 10 \mathrm{E}$ and altitude $213 \mathrm{~m}$ ) and Vegetable Seed Lab, Institute of Horticultural Sciences, University of Agriculture Faisalabad Pakistan, to optimize the plant spacing for improving carrot seed yield and quality.

\section{Experimental details}

Carrot cv. T-29 seeds were sown on both sides of raised beds prepared $75 \mathrm{~cm}$ apart. First irrigation just after seed sowing was applied, while later irrigations were applied depending upon the requirement of crop. Mature roots of carrot were used for preparation of stecklings 120 days after sowing. Small sized and poor coloured roots along with, split, damaged and branched roots were discarded and healthy large sized roots with $25-30 \mathrm{~cm}$ long and 7-9 cm in width [19], were chosen to make stecklings for seed production. Stecklings were prepared by removing lower $1 / 3^{\text {rd }}$ portion of the root and also keeping leaf bases (about $5 \mathrm{~cm}$ ) intact. For plantation of stecklings, land was prepared to a good tilth and one third dose of nitrogen, full dose of phosphorus and potash was applied before ridges preparation, 
however remaining nitrogen was applied in two splits [20]. Stecklings having uniform size were planted at the top of ridges, which were $75 \mathrm{~cm}$ apart, at three different spacings viz., $S_{1}(15 \mathrm{~cm}), S_{2}(22.5 \mathrm{~cm}), S_{3}(30 \mathrm{~cm})$. Field was irrigated after plantation of stecklings and sprayed with Stomp Xtra (FMC Limited) within 24 hours of irrigation. Seed crop was harvested 120 days after planting of stecklings.

\section{Data collection}

Number of umbels per plant and yield traits (seed weight of different order umbels per plant and plot) were recorded. Quality traits (1000-seed weight, germination percentage, seedling vigor index, germination index, time taken to 50 percent germination $\left[\mathrm{T}_{50}\right]$ ) and seedling length were studied for seeds from umbels of various orders, essentially as mentioned elsewhere [20]. Sample size for data collection was ten plants or seedlings, selected randomly, in case of plants in field and germination test, respectively.

\section{Seed quality assessment}

Seeds from three above mentioned umbel orders were extracted separately and used to determine 1000-seed weight as well as germination and vigour related parameters. Germination test was accomplished for 7 days at $24 \pm 2{ }^{0} \mathrm{C}$, with four replicates of 25 seeds harvested from all umbels order for each treatment following rules of Association of Official Seed Analysts (AOSA) [21]. It was performed six months after harvesting, at the time of sowing of carrot root crop, to provide a true picture of seed germination for growing season. Seedling length of ten normal seedlings was measured with the help of measuring scale in each replication. Vigour index was calculated as described by [22], while time taken to 50 percent germination ( $\left.\mathrm{T}_{50}\right)$ was determined as described by [23]. Germination index (GI) was calculated as described by the AOSA [24].

\section{Experimental layout and statistical analysis}

The experiment was conducted by arranging treatments according to randomized complete block design with three replication of each treatment in field experiment while four replicates in germination trial. The data collected were analyzed statistically by using the analysis of variance technique in statistical package Statistix 8.1. Difference among treatments means at $5 \%$ probability level were compared by using Tukey's test.

\section{Results}

Planting geometry of carrot seed crop significantly affected the number of umbels per plant of cv. T-29 (Table 1). Maximum secondary umbels per plant (9.85) were documented with widest spacing at $30 \mathrm{~cm}$, but were noted lowest (7.61) with plant spacing at $15 \mathrm{~cm}$. Number of secondary umbels were $29.4 \%$ higher at widest spacing, i.e. $30 \mathrm{~cm}$, compared with closest $(15 \mathrm{~cm})$ spacing. Highest tertiary umbels per plant (9.02) exhibited at $30 \mathrm{~cm}$ spacing that was statistically alike to $22.5 \mathrm{~cm}$ spacing, being $17.7 \%$ more number of tertiary umbels per plant compared with the closest spacing at 15 cm (Table 1).

Seed production of carrot was significantly affected by the plant spacing. Seed weight per umbel differed significantly among the three spacings and were significantly higher at widest spacing (Table 1). Plants spaced 30 $\mathrm{cm}$ apart produced higher seed weight from primary (8.96 g), secondary (22.83 g) and tertiary umbels $(8.96 \mathrm{~g})$ than those spaced 15 $\mathrm{cm}$ apart, being 25.8, 33.8 and 20.6\% higher seed weight than the closest spacing from all umbels order i.e. primary, secondary and tertiary umbels, respectively. Highest planting density at $30 \mathrm{~cm}$ gave noticeably (28.9\%) higher yield of seed per plant (40.76 g) as compared to other spacings but exhibited the lowest seed yield per plot $(693.1 \mathrm{~g})$. Seed yield per plot was highest at $15 \mathrm{~cm}$ spacing and exhibited $28.3 \%$ increase 
$(889.4 \mathrm{~g})$ at closest spacing compared with the widest $(30 \mathrm{~cm})$ spacing (Table 1$)$.

Planting density effects on seed quality were more variable. Weight of 1000-seeds increased at wider plant spacing. Higher value of 1000-seed weight from primary $(4.29 \mathrm{~g})$, secondary (2.86 g) and tertiary umbels (1.69 g) was observed for spacing at $30 \mathrm{~cm}$, while, it was observed minimum for spacing at $15 \mathrm{~cm}(3.45,2.39$ and $1.26 \mathrm{~g}$, respectively), i.e. $24.3,19.6$ and $34.1 \%$ higher than the closest $(15 \mathrm{~cm})$ spacing from all umbels order, respectively (Table 2). However, there was no significant difference in germination percentage of seeds from primary and secondary umbels of plants spaced $15 \mathrm{~cm}, 22.5 \mathrm{~cm}$ and $30 \mathrm{~cm}$, but, germination percentage of tertiary umbel seeds $(64.0 \%)$ of $30 \mathrm{~cm}$ spaced plants was highest followed by $22.5 \mathrm{~cm}$ spaced plants $(62.0 \%)$ and minimum for $15 \mathrm{~cm}$ spaced plants $(58.6 \%$ ) (Table 2). Vigour index of seeds from all umbel order were significantly altered due to plant spacing (Table 3 ).

Table 1. Impact of spacing on number of umbels and seed yield of carrot cv. T-29

\begin{tabular}{|c|c|c|c|c|c|c|c|}
\hline \multirow{2}{*}{$\begin{array}{c}\text { Treatments } \\
\text { (Intra-row } \\
\text { Spacing) }\end{array}$} & \multicolumn{2}{|c|}{$\begin{array}{c}\text { Number of umbels per } \\
\text { plant }\end{array}$} & \multicolumn{5}{|c|}{ Seed yield (g) } \\
\hline & $\begin{array}{c}\text { Sec. } \\
\text { umbels }\end{array}$ & Ter. Umbels & $\begin{array}{c}\text { Pri. } \\
\text { umbel }\end{array}$ & $\begin{array}{c}\text { Sec. } \\
\text { umbels }\end{array}$ & $\begin{array}{c}\text { Ter. } \\
\text { umbels }\end{array}$ & $\begin{array}{c}\text { Per } \\
\text { plant }\end{array}$ & $\begin{array}{l}\text { Per } \\
\text { plot }\end{array}$ \\
\hline S1 (15 cm) & $7.61 \mathrm{~b}$ & $7.66 \mathrm{~b}$ & $7.12 \mathrm{c}$ & $17.06 \mathrm{c}$ & $7.43 \mathrm{c}$ & $31.62 \mathrm{c}$ & $889.4 \mathrm{a}$ \\
\hline $\mathrm{S2}(22 \mathrm{~cm})$ & $8.05 \mathrm{~b}$ & $8.56 \mathrm{a}$ & $7.86 \mathrm{~b}$ & $20.03 \mathrm{~b}$ & $8.12 \mathrm{~b}$ & $36.02 \mathrm{~b}$ & $742.2 \mathrm{~b}$ \\
\hline$S 3(30 \mathrm{~cm})$ & $9.85 \mathrm{a}$ & $9.02 \mathrm{a}$ & $8.96 \mathrm{a}$ & $22.83 \mathrm{a}$ & $8.96 \mathrm{a}$ & $40.76 \mathrm{a}$ & $693.1 \mathrm{c}$ \\
\hline
\end{tabular}

Mean values having similar letters in a column are statistically similar to each other $(\mathrm{P} \leq 0.05)$ according to Tukey Test. Primary (Pri.); Secondary (Sec.); Tertiary (Ter.)

Table 2. Spacing effects on thousand seed weight and germination of primary, secondary and tertiary umbel seeds of carrot cv. T-29

\begin{tabular}{|c|c|c|c|c|c|c|}
\hline \multirow{2}{*}{$\begin{array}{c}\text { Treatments } \\
\text { (Intra-row } \\
\text { Spacing) }\end{array}$} & \multicolumn{2}{|c|}{ Weight of 1000 seeds (g) from } & \multicolumn{3}{c|}{ Germination (\%) of seeds from } \\
\cline { 2 - 7 } & $\begin{array}{c}\text { Pri. } \\
\text { umbel }\end{array}$ & $\begin{array}{c}\text { Sec. } \\
\text { umbels }\end{array}$ & $\begin{array}{c}\text { Ter. } \\
\text { umbels }\end{array}$ & $\begin{array}{c}\text { Pri. } \\
\text { umbel }\end{array}$ & $\begin{array}{c}\text { Sec. } \\
\text { umbels }\end{array}$ & $\begin{array}{c}\text { Ter. } \\
\text { umbels }\end{array}$ \\
\hline S1 (15 cm) & $3.45 \mathrm{c}$ & $2.39 \mathrm{~b}$ & $1.26 \mathrm{c}$ & $88.0 \mathrm{a}$ & $86.0 \mathrm{a}$ & $58.6 \mathrm{~b}$ \\
\hline S2 (22 cm) & $3.86 \mathrm{~b}$ & $2.64 \mathrm{a}$ & $1.53 \mathrm{~b}$ & $90.0 \mathrm{a}$ & $88.0 \mathrm{a}$ & $62.0 \mathrm{ab}$ \\
\hline S3 (30 cm) & $4.29 \mathrm{a}$ & $2.86 \mathrm{a}$ & $1.69 \mathrm{a}$ & $92.0 \mathrm{a}$ & $90.0 \mathrm{a}$ & $64.0 \mathrm{a}$ \\
\hline
\end{tabular}

Mean values having same letters in a column are statistically similar to each other $(\mathrm{P} \leq 0.05)$ according to Tukey Test. Primary (Pri.); Secondary (Sec.); Tertiary (Ter.)

Table 3. Vigour index and germination index of primary, secondary and tertiary umbel seeds of carrot cv. T-29 in response to mother plant spacing

\begin{tabular}{|c|c|c|c|c|c|c|}
\hline \multirow{2}{*}{$\begin{array}{c}\text { Treatments } \\
\text { (Intra-row } \\
\text { Spacing) }\end{array}$} & \multicolumn{3}{|c|}{ Vigour index of seeds from } & \multicolumn{3}{|c|}{ Germination index of seeds from } \\
\hline & $\begin{array}{c}\text { Primary } \\
\text { umbel }\end{array}$ & $\begin{array}{c}\text { Secondary } \\
\text { Umbels }\end{array}$ & $\begin{array}{l}\text { Tertiary } \\
\text { umbels }\end{array}$ & $\begin{array}{c}\text { Primary } \\
\text { umbel }\end{array}$ & $\begin{array}{c}\text { Secondary } \\
\text { Umbels }\end{array}$ & $\begin{array}{c}\text { Tertiary } \\
\text { umbels }\end{array}$ \\
\hline $\mathrm{S1}(15 \mathrm{~cm})$ & $724.6 \mathrm{c}$ & $696.3 \mathrm{c}$ & $283.5 \mathrm{~b}$ & $30.6 \mathrm{~b}$ & $29.1 \mathrm{~b}$ & $13.0 \mathrm{~b}$ \\
\hline $\mathrm{S2}(22 \mathrm{~cm})$ & $800.5 \mathrm{~b}$ & $768.2 \mathrm{~b}$ & $322.3 \mathrm{ab}$ & $34.1 \mathrm{a}$ & $32.3 \mathrm{a}$ & $15.3 \mathrm{ab}$ \\
\hline $\mathrm{S3}(30 \mathrm{~cm})$ & $867.2 \mathrm{a}$ & $822.0 \mathrm{a}$ & $363.1 \mathrm{a}$ & $36.0 \mathrm{a}$ & $34.0 \mathrm{a}$ & $18.1 \mathrm{a}$ \\
\hline
\end{tabular}

Mean values having same letters in a column are statistically similar to each other $(\mathrm{P} \leq 0.05)$ according to Tukey Test. Primary (Pri.); Secondary (Sec.); Tertiary (Ter.)

It can be observed from the results that highest vigour index of seeds from primary
(867.2), secondary (822.0) and tertiary (363.1) umbels was noticed in the seed 
obtained from the plant grown at wider (30 $\mathrm{cm})$ spacing. Moreover, vigor index of seeds collected from $30 \mathrm{~cm}$ spaced plants was 19.67, 18.05 and $28.07 \%$ higher from all umbels order respectively, compared with those spaced $15 \mathrm{~cm}$ apart. Germination index was highest for widest plant spacing at $30 \mathrm{~cm}$ and increased up to $17.64,16.8$ and $39.2 \%$ from primary, secondary and tertiary umbel order seeds, respectively, compared to narrowest $(15 \mathrm{~cm})$ plant spacing (Table 3 ). Results revealed significant differences for time taken to 50 percent germination $\left(\mathrm{T}_{50}\right)$ among spacing levels (Table 4). Seed from widely spaced plants exhibited reduced time for 50 percent germination i.e. 14.8, 24.1 and $21.2 \%$ reduction from primary, secondary and tertiary umbels, respectively, at $30 \mathrm{~cm}$ spacing. It can be observed from the results that seedling length was maximum for seeds of primary $(9.43 \mathrm{~cm})$, secondary $(9.13 \mathrm{~cm})$ and tertiary umbel order $(5.66 \mathrm{~cm})$ of widely spaced plants $(30 \mathrm{~cm})$, i.e. $14.5,12.7$ and $17.1 \%$ higher than the closest $(15 \mathrm{~cm})$ spacing.

Table 4. Effect of spacing on $\mathbf{T}_{50}$ and seedling length of primary, secondary and tertiary umbel seeds of carrot cv. T-29

\begin{tabular}{|c|c|c|c|c|c|c|}
\hline \multirow{2}{*}{$\begin{array}{c}\text { Treatments } \\
\text { (Intra-row } \\
\text { Spacing) }\end{array}$} & \multicolumn{2}{|c|}{ T $_{\mathbf{5 0}}$ (days) of seeds from } & \multicolumn{3}{c|}{ Seedling length (cm) of seeds from } \\
\cline { 2 - 7 } & $\begin{array}{c}\text { Pri. } \\
\text { umbel }\end{array}$ & $\begin{array}{c}\text { Sec. } \\
\text { umbels }\end{array}$ & $\begin{array}{c}\text { Ter. } \\
\text { umbels }\end{array}$ & $\begin{array}{c}\text { Pri. } \\
\text { umbel }\end{array}$ & $\begin{array}{c}\text { Sec. } \\
\text { umbels }\end{array}$ & $\begin{array}{c}\text { Ter. } \\
\text { umbels }\end{array}$ \\
\hline S1 (15 cm) & $0.85 \mathrm{a}$ & $0.87 \mathrm{a}$ & $1.32 \mathrm{a}$ & $8.23 \mathrm{c}$ & $8.1 \mathrm{~b}$ & $4.83 \mathrm{~b}$ \\
\hline S2 (22 cm) & $0.77 \mathrm{ab}$ & $0.78 \mathrm{a}$ & $1.29 \mathrm{a}$ & $8.83 \mathrm{~b}$ & $8.66 \mathrm{a}$ & $5.21 \mathrm{~b}$ \\
\hline S3 (30 cm) & $0.74 \mathrm{~b}$ & $0.66 \mathrm{~b}$ & $1.04 \mathrm{~b}$ & $9.43 \mathrm{a}$ & $9.13 \mathrm{a}$ & $5.66 \mathrm{a}$ \\
\hline
\end{tabular}

Mean values having same letters in a column are statistically similar to each other $(\mathrm{P} \leq 0.05)$ according to Tukey Test. Primary (Pri.); Secondary (Sec.); Tertiary (Ter.)

\section{Discussion}

Row spacing alters structure of plant, photosynthetic rate and distribution of dry matter in several agronomic and horticultural crops $[11,15,25,26]$. Total umbels per plant were increased through widest $(30 \mathrm{~cm})$ plant spacing. The difference in spacing brought significant variation in seed yield components. Number of harvested umbels per plant was higher in wider spacing than the closer spacing, which seems to be mainly due to less competition for nutrition and light. This less competition might have augmented more branching, ultimately producing more umbels per plant. Wider spacing $(60 \times 60 \mathrm{~cm})$ resulted in higher umbels per plant, greater mass and size of umbel in carrot crop [27]. Similar results were found in cauliflower by Rahman et al. [26].

Results depicted that seed yield parameters were greatly influenced by plant spacing and widest spacing produced highest seed weight per umbel of carrot seed crop. This increased production of seed per plant may be owing to well establishment of the plant which in turn resulted in production of maximum umbels per plant. Enhanced seed quantity at wider spacing due to less competition than dense spacing in rice was also stated by Dass et al. [28]. In contrast, seed yield per plot was higher for closely spaced plants because plants population was high that eventually enhanced seed production. Previously, increased seed yield of carrot due to closely spaced plants has been reported by some researchers [19, 29, 30]. Higher seed yield in closely spaced plots than at wider spacing had also been reported in forage turnip [17]. Similarly, seed yield of fodder radish was enhanced with increase in plant population due to close plant spacing [18], which confirms our outcomes.

Seed quality is assessed by determining seed size, seed germination potential and vigour 
index. It was observed that weight of 1000seeds, which reflects seed size and ultimately improve seed yield and its quality [31], was higher from widely spaced plants compared with closely spaced plants indicating better uptake of nutrients and improved photosynthetic efficiency of plants and photosynthate accumulation in developing seeds [32]. Increase in 1000-grain weight of rice has been reported at wider spacing than closer spacing by [13]. Wider spacing had substantial effects on weight of 1000 seed of cotton and onion seeds but did not affect the germination percentage $[33,34]$. In line with these results of other researchers, carrot seed crop spacing did not influence germination of primary and secondary umbel seeds but slightly decreased germination of seeds collected from 22.5 and $15 \mathrm{~cm}$ spaced plants. Previously, it has been reported that spacing did not affect germination but improved vigour in radish [18] because of adequate photosynthates availability to be accumulated in seeds under wider spacing conditions [35]. Same pattern was observed in vigour of seeds from all umbel orders of widely $(30 \mathrm{~cm})$ spaced plants that was significantly better than seed vigour of closely $(15 \mathrm{~cm})$ spaced plants. Moreover, germination index also indicated that both 30 and $22.5 \mathrm{~cm}$ spaced plants were statistically similar and better than $15 \mathrm{~cm}$ spaced plants. It is an already established fact that seed germination and vigour are correlated with seedling emergence of soybeans in field [36, 37]. Yagushi et al. [38] also described that there was strong positive correlation between soybean seedling emergence in field and vigour index after six months of storage. Moreover, they showed that high quality seed lots exhibiting high germination and vigour maintained their germination and vigour even when stored under controlled $\left(20^{\circ} \mathrm{C}\right.$ and $70 \%$ R.H.) and ambient conditions. Therefore, it can be concluded from the results that seeds of $15 \mathrm{~cm}$ spaced plants can be stored, but for a shorter duration (probably up to one year under normal storage conditions) compared to $30 \mathrm{~cm}$ spaced plants. So, seeds from closely spaced plants can reliably be used for sowing during normal season. But, such seed should be used with caution for early season sowing, when temperature is high during late summer months in Punjab; usually at higher rate than normal, because of low vigour

\section{Conclusion}

Seed obtained from widely spaced $(30 \mathrm{~cm})$ plants was better in almost all aspects except seed yield per plot that was higher for narrow intra-row spacings $(15 \mathrm{~cm})$ but at the expense of seed quality. So, $30 \mathrm{~cm}$ plant spacing would be beneficial for enhancing seed quality of carrot. Based on this study, it may be concluded that carrot seed crop (stecklings) should be planted at spacing of $30 \mathrm{~cm}$ for higher quality seed followed by 22 $\mathrm{cm}$.

\section{Authors' contributions}

Conceived and designed the experiments: $\mathrm{K}$ Ziaf, Performed the experiments: A Noor, Analyzed the data: MA Ghani, Contributed materials/ analysis/ tools: CM Ayub \& M Amjad, Wrote the paper: K Ziaf \& I Ahmad.

\section{Acknowledgments}

The authors highly acknowledge the Endowment Fund Secretariat (EFS), University of Agriculture, Faisalabad for funding to carry out this study, vide Project No. 574, "Dissemination of Seed Production Technology of Important Crops (Component I: Vegetable Seed Production)".

\section{References}

1. Que F, Xi-Lin H, Guang-Long W, ZhiSheng X, Guo-Fei T, Tong L, Ya-Hui W, Khadr A \& Ai-Sheng X (2019). Advances in research on the carrot, an important root vegetable in the Apiaceae family. Hortic Res 6(69): 1-15.

2. Arscott SA \& Tanumihardjo SA (2010). Carrots of many colors provide basic nutrition and bioavailable phytochemicals acting as a functional food. Compr Rev Food Sci Food Saf 9: 223-239. 
3. Majoka M, Panghal VPS, Duhan DS, Kumar HRK \& Rani S (2019). Effect of plant density on seed production of carrot var. Hisar Gairic. J Pharmacogn Phytochem 5: 99-102.

4. FAOSTAT (2014). Crop Production Data. Available online with updates at http://faostat.fao.org/site/345/default.aspe $\mathrm{x}$

5. Anonymous (2019). Fruit, vegetables and condiments statistics of Pakistan. Government of Pakistan, Ministry of National Food Security and Research, Economic wing, Islamabad, Pakistan.

6. Ahmad B, Hassan S \& Bakhsh K (2005). Factors affecting yield and profitability of carrot in two districts of Punjab. Int J Agric Biol 5: 794-798.

7. Dawit A, Abera D, Lemma D \& Chimdo A (2004). Domestic vegetable seed production and marketing. Research report No. 57, EARO. Addis Ababa.

8. Ziaf K, Mahmood-ur-Rehman M, Amjad M, Ahmad R, Batool A, Muhammad A, Latif J \& Zaman QU (2017). Influence of hydro-and halo-priming on germination and seedling growth of cabbage under saline conditions. Pure Appl Biol 6(1): 97107.

9. Pereira RS, Nascimento WM \& Vieira V (2008). Carrot seed germination and vigor in response to temperature and umbel orders. Sci Agric 65: 145-150.

10. Kumar A, Afroza B, Jabeen N \& Mushtaq N (2017). Manipulation of plant spacing and steckling size to increase growth and seed yield in carrot (Daucus carota L.) under temperate conditions of Kashmir. Vegetos 30(4): 1-2.

11. Singh AK, Bhatt BP, Sundaram PK, Gupta AK \& Singh D (2013). Planting geometry to optimize growth and productivity in faba bean (Vicia faba L.) and soil fertility. J Environ Biol 34: 117-22.

12. Baumhardt RL, Schwartz RC, Marek GW \& Bell JM. 2018. Planting geometry effects on the growth and yield of dryland cotton. Agric Sci 9: 99-116.
13. Ashraf U, Abbas RN, Hussain S, Mo ZW, Anjum SA, Khan I \& Tang XR (2016). Consequences of varied planting geometry and early post emergence herbicides for crop-weed interventions in rice under semi-arid climate. Planta Daninha Viçosa-MG 34: 737-746.

14. Kang ES, Ha SM, Cheong SR, Seo MW, Kwack YB, Choi KJ \& Chae WB (2015). Optimum double-row spacing in the autumn cultivation of radish (Raphanus sativus L.). Korean J Environ Agric 34: 204-209.

15. Horbe TA, Amado TJ, Reimche GB, Schwalbert RA, Santi AL \& Nienow C (2016). Optimization of within-row plant spacing increases nutritional status and corn yield: A comparative study. Agron J 108: 1962-1971.

16. Chhetri RK, Panta R \& Shrestha RK (2019). Effect of spacing and potassium application on growth and yield of radish Raphanus Sativus cv. Mino Early. Int J Biol Res 2(1): 176- 180.

17. Bilgili U, Sincik M, Uzun A \& Acikgoz E (2003). The influence of row spacing and seeding rate on seed yield and yield components of forage turnip (Brassica rapa L.). J Agron Crop Sci 189: 250-254.

18. Oliveira ADS, Carvalho MLMD, Nery MC, Oliveira JA \& Guimarães RM (2011). Seed quality and optimal spatial arrangement of fodder radish. Sci Agric 68: 417-423.

19. Anjum MA \& Amjad M (2002). Influence of mother root size and plant spacing on carrot seed production. J Res Sci 13(2): 105-112.

20. Noor, A, Ziaf K, Amjad M \& Ahmad I (2020) Synthetic auxins concentration and application time modulates seed yield and quality of carrot by altering umbel order. Sci Hortic 262.

21. Association of Official Seed Analysts (AOSA) (1990). Rules for testing seeds. $J$ Seed Technol 12: 1-112.

22. Abdul-Baki A \& Anderson JD (1973). Vigor determination in Soybean seed by multiple criteria. Crop Sci 13: 630-633. 
23. Farooq M, Basra SMA, Hafeez K \& Warriach EA (2004). Influence of high and low temperature treatments on the seed germination and seedling vigor of coarse and fine rice. Int Rice Res 29: 69-71.

24. Association of Official Seed Analysts (AOSA) (1983). Seed Vigor Testing Hand Book. Contribution No. 32 to the Handbook on Seed Testing. Association of Official Seed Analysis, Springfield, IL.

25. Hussain M, Mehmood Z, Khan MB, Farooq S, Lee DJ \& Farooq M (2012). Narrow row spacing ensures higher productivity of low tillering wheat cultivars. Int J Agric Biol 14: 413-418.

26. Rahman M, Iqbal M, Jilani MS \& Waseem $\mathrm{K}$ (2007). Effect of different plant spacing on the productiion of cauliflower (Brassica oleracea var botrytis). Pak J Bio Sci 10: 4531-4534.

27. Ahmad N \& Tanki MI (1997). Effect of planting date, spacing and steckling size on growth and seed yield of carrot (Daucus carota L.). Hayana J Hort Sci 26: 274276.

28. Dass A, Chandra S, Choudhary AK, Singh G \& Sudhishri S (2016). Influence of field re-ponding pattern and plant spacing on rice root-shoot characteristics, yield, and water productivity of two modern cultivars under SRI management in Indian Mollisols. Paddy Water Environ 14: 4559.

29. Mengistu T \& Yamoah C (2010). Effect of sowing date and planting density on seed production of carrot (Daucus carota var. sativa) in Ethiopia. Afr J Plant Sci 4(8): 270-279.

30. Sutradhar H, Pandita VK, Tomar BS \& Yadav RN (2018). Influence of planting ratio and plant spacing on hybrid seed yield and quality in tropical carrot cv. Pusa Vasuda. Indian J Agri Sci 88(1): 145-148.

31. Ali I, Mahmood MT, Akhtar MI, Zafar A, Khan AM, Zubair M \& Anum W (2019). Some direct and indirect selection indices for increased yield of peas (Pisum sativum L.). J Environ Agric Sci 21: 23-28.

32. Kuai J, Sun Y, Zuo Q, Huang H, Liao Q, Wu C \& Zhou G (2015). The yield of mechanically harvested rapeseed (Brassica napus L.) can be increased by optimum plant density and row spacing. Sci Rep 5(18835): 1-14.

33. Zena Z (2013). The effect of bulb size and plant density on yield and quality of onion (Allium cepa L.) seeds at Ziway, Central Ethiopia. $1^{\text {st }}$ Ed. GRIN Verlag Gmbh; Germany, pp 46.

34. Awan H, Awan I, Mansoor M, Khan EA \& Khan MA (2011). Effect of sowing time and plant spacing on fiber and cotton seed yield and quality. Sarhad J Agric 27(3): 411-413.

35. Kamboj NK, Sharma HD (2015) Effect of planting time and spacing on maturity, growth and fruit yield of bell pepper. Inter J Farm Sci 5: 17-23.

36. Egli DB, TeKrony DM (1995) Soybean seed germination, vigor and field emergence. Seed Sci Technol 23: 595-607.

37. Schuab SRP, Braccini AL, Scapim CA, França-Neto JB, Meschede DK \& Avila MR (2007). Germination test under water stress to evaluate soybean seed vigour. Seed Sci Technol 35: 187-199.

38. Yagushi JT, Costa DS, França-Neto JB (2014). Saturated salt accelerated aging and computerized analysis of seedling images to evaluate soybean seed performance. J Seed Sci 36(2): 213-221. 